\title{
PENGARUH PENGGUNAAN FASILITAS BELAJAR DI LINGKUNGAN ALAM SEKITAR TERHADAP KETERAMPILAN PROSES SAINS
}

\author{
DWI APRILLIA SETIA ASIH \\ dwiaprillia203@gmail.com \\ Program Studi Pendidikan Biologi, Fakultas Teknik, Matematika, dan IPA \\ Universitas Indraprasta PGRI
}

\begin{abstract}
Abstrak. Fisika sering kali dianggap pelajaran yang paling sulit dikuasai oleh karena itu diperlukan model pembelajaran yang mampu membantu serta dapat memanfaatkan apa yang disediakan oleh alam yaitu dengan menggunakan model pembelajaran berbasis lingkungan (menggunakan fasilitas belajar di lingkungan alam sekitar dalam proses pembelajaran). Penelitian ini bertujuan untuk mengetahui adanya pengaruh penggunaan fasilitas belajar di lingkungan alam sekitar terhadap keterampilan proses sains. Penelitian ini merupakan penelitian eksperimen semu dengan menggunakan dua kelompok yang akan diteliti yaitu kelompok pertama mendapatkan perlakuan (treatment) atau kelompok yang menggunakan fasilitas belajar di lingkungan alam sekitar disebut kelas eksperimen, sedangkan kelompok yang kedua merupakan kelompok pengendali atau kelompok kontrol dimana kelompok ini menggunakan fasilitas belajaryang biasa digunakan dalam proses pembelajaran. Penentuan sampel menggunakan teknik cluster random sampling, instrument yang digunakan adalah lembar observasi. Pengambilan data menggunakan metode observasi. Analisis dalam penelitian ini menggunakan uji paired t-test (uji perbedaan dua rata-rata). Berdasarkan analisis data diperoleh hasil uji perbedaan dua ratarata data $t_{\text {daf }}(\alpha=5 \%)=1,67$ dant $_{\text {daf }}(\alpha=1 \%)=2,39$ sedangkan $t_{\text {hit }}=6,04$. Sehingga $t_{\text {hit }}>$

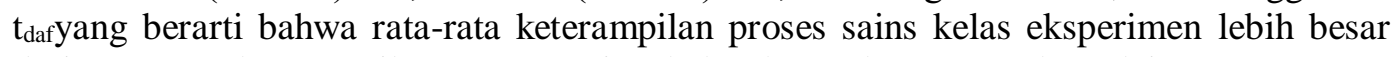
dari rata-rata keterampilan proses sains kelas kontrol. Dengan kata lain, penggunaan fasilitas belajar di lingkungan alam sekitar memiliki pengaruh yang signifikan terhadap keterampilan proses sains. Keberhasilan peningkatan keterampilan proses sains disebabkan karena dampak dari penggunaan fasilitas belajar di lingkungan alam sekitar.
\end{abstract}

Kata Kunci: Fasilitas Belajar di Lingkungan Alam Sekitar, dan Keterampilan Proses Sains.

\section{PENDAHULUAN}

Fisika merupakan salah satu ilmu yang berkembang dari pengamatan gejala alam dan interaksi yang terjadi di dalamnya. Terdapat banyak penerapan ilmu fisika yang dapat kita jumpai dalam kehidupan sehari-hari seperti kapal selam, balon udara, jembatan ponton, katrol, kincir angin dan sepeda motor. Permendiknas No. 23 tahun 2006 tentang Standar Kompetensi Lulusan (SKL) disebutkan bahwa fisika merupakan salahsatu cabang IPA yang mendasari perkembangan teknologi maju dan konsep hidup harmonis dengan alam. Hakikat pembelajaran Sains atau Ilmu Pengetahuan Alam yaitu terdiri dari konten atau produk, proses atau model, dan sikap. Sains sebagai konten atau produk berarti di dalam sains terdapat fakta-fakta, prinsip-prinsip, hukum-hukum, dan teori-teori yang sudah dapat dibuktikan kebenarannya. Sains sebagai proses atau model berarti bahwa sains merupakan suatu proses atau model untuk mendapatkan pengetahuan. Sains juga merupakan sikapyang berarti bahwa di dalam sains terdapat sikap seperti tekun, terbuka, teliti, jujur dan objektif.

Trianto (2013) menyatakan bahwa IPA adalah suatu kumpulan teori yang sistematis, penerapannya secara umum terbatas pada gejala-gejala alam, lahir dan 
berkembang secara ilmiah seperti observasi dan eksperimen serta menuntut sikap ilmiah. Hal tersebut menunjukkan bahwa pembelajaran fisika merupakan suatu ilmu yang harus dipelajari melalui pengamatan langsung. Berdasarkan hasil observasi di lapangan menunjukkan bahwa sebagian guru di SMP masih menggunakan metode ceramah sebagai metode pembelajaran di kelas. Pembelajaran IPA khususnya fisika saat ini belum mengarahkan siswa untuk menemukan pengetahuannya sendiri, kenyataan di lapangan siswa hanya menghafal konsep dan kurang mampu mengaplikasikan konsep terhadap masalah dalam kehidupan nyata. Berdasarkan hasil temuan di lapangan dengan teori yang ada terdapat penyimpangan, sehingga mengakibatkan keterampilan proses sains pada mata pelajaran fisika rendah. Oleh karena itu diperlukan sebuah model pembelajaran yang mampu membantu guru menyampaikan materi serta dapat memanfaatkanapa yang disediakan oleh alam untuk siswa dapat melakukan pengamatan secara lansung yaitu dengan menggunakan model pembelajaran berbasis lingkungan.

Model pembelajaran berbasis lingkungan merupakan model pembelajaran yang menggunaan fasilitas belajar dari lingkungan alam sekitar sebagai sumber belajar, hal tersebut sangat dianjurkan untuk digunakan dengan tujuan mengembangkan keterampilan proses sains siswa. Sehingga penggunaan fasilitas belajar berpengaruh terhadap keterampilan proses sains dan hasil belajar. Hal tersebut senada dengan pendapat Irhash (2008) bahwa " fasilitas belajar adalah semua kebutuhan yang diperlukan oleh peserta didik dalam rangka untuk memudahkan, melancarkan dan menunjang dalam kegiatan belajar disekolah. Supaya lebih efektif dan efisien yang nantinya peserta didik dapat belajar dengan maksimal dan hasil belajar yang memuaskan".

Misbach (2011) menyatakan bahwa "fasilitas belajar merupakan salah satu faktor yang mempengaruhi interaksi belajar mengajar. Interaksi belajar mengajar akan semakain produktif apabila antara siswa, guru, dan materi pelajaran didukung oleh sarana dan prasarana yang memadai serta pengelolaan yang baik sehingga dapat menghasilkan sesuatu yang bermakna". Adapun fasilitas yang seharusnya dimiliki oleh pihak sekolah untuk menunjang proses belajar mengajar antara lain gedung sekolah, ruang kelas, perpustakaan, laboratorium, dan media pengajaran (Soetopo Cit Sam, 2011). Berdasarkan pendapat diatas dapat dikemukakan bahwa fasilitas belajar adalah segala sesuatu yang dapat menunjang dan mempermudah kegiatan belajar mengajar. Fasilitas belajar yang dimaksud adalah sarana pendidikan yang ada di lingkungan sekolah berupa, gedung atau ruang kelas, halaman, kebun, taman sekolah dan peralatan pendukung di dalamnya, media pembelajaran, buku atau sumber belajar lainya.

Fisika sebagai mata pelajaran yang dapat mengajarkan siswa memiliki keterampilan proses sains. Hal ini perlu menjadi perhatian bagi guru-guru yang mengajar sehingga dalam pembelajaran fisika disamping bertujuan mencapai penguasaan konsep oleh siswa juga dapat membentuk siswa memiliki keterampilan proses sains. Berdasarkan kondisi yang ada maka diperlukan suatu model pembelajaran untuk memperbaiki keterampilan proses sains. Menurut Indrawati Cit Trianto (2010) bahwa "keterampilan proses merupakan keseluruhan keterampilan ilmiah (baik kognitif maupun psikomotor) yang dapat digunakan untuk menemukan suatu konsep atau prinsip, untuk mengembangkan konsep yang telah ada sebelumnya, ataupun untuk melakukan penyangkalan terhadap suatu penemuan atau klasifikasi”. Keterampilan proses sains merupakan keterampilan yang harus dikembangkan pada anak didik agar konsep pengetahuan yang dimilikinya bisa dikembangkan.

Menurut Mudjiono (2006) bahwa "ada berbagai keterampilan dalam keterampilan proses, terdiri dari keterampilan-keterampilan dasar (basic skills) dan ketrampilanketerampilan terintegrasi (integrated skills). Keterampilan-keterampilan dasar terdiri dari enam keterampilan, yakni: mengobservasi, mengklasifikasi, memprediksi, mengukur, 
menyimpulkan, dan mengkomunikasikan”. Menurut Rezba dan Wetzel Cit Mahmudin (2011), menyatakan bahwa: Keterampilan proses sains terpadu meliputi: melakukan pengamatan (Observasi), menafsirkan pengamatan (Interpretasi), mengelompokkan (Klasifikasi), meramalkan (Prediksi), berkomunikasi, berhipotesis, merencanakan percobaan atau penyelidikan, menerapkan konsep atau prinsip, mengajukan pertanyaan. Berdasarkan latar belakang tersebut, peneliti memilih suatu model pembelajaran yang diharapkan dapat meningkatkan keterampilan proses sains yaitu menggunakan fasilitas belajar di lingkungan alam sekitar. Karena model pembelajaranini diharapkan akan menciptakan suasana pembelajaran yang lebih kontekstual, merangsang berbagai kemampuan siswa dalam proses pembelajaran dan menciptakan proses belajar yang lebih bermakna sebab siswa dihadapkan pada kondisi yang sebenarnya. Hal tersebut senada dengan pendapat Hamzah (2011) bahwa "konsep pembelajaran dengan menggunakan lingkungan memberikan peluang yang sangat besar kepada peserta didik untuk meningkatkan hasil belajarnya, dan secara umum konsep pembelajaran dengan menggunakan lingkungan dapat meningkatkan motivasi belajar dari peseta didik".

Berdasarkan uraian latar belakang di atas, maka dilakukan penelitian dengan judul "pengaruh penggunaan fasilitas belajar di lingkungan alam sekitar terhadap keterampilan proses sains". Penelitian ini bertujuan untuk mengetahui adanya pengaruh penggunaan fasilitas belajar di lingkungan alam sekitar terhadap keterampilan proses sains.

\section{METODE}

Penelitian ini menggunakan metode penelitian eksperimen semu, dalam penelitian ini menggunakan dua kelompok yang akan di teliti yaitu kelompok pertama mendapatkan perlakuan (treatment) atau kelompok yang menggunakan fasilitas belajar di lingkungan alam sekitar disebut kelas eksperimen, sedangkan kelompok yang kedua merupakan kelompok pengendali atau kelompok kontrol dimana kelompok ini menggunakan fasilitas belajaryang biasa digunakan dalam proses pembelajaran, serta menggunakan dua variabel yang akan di teliti yaitu fasilitas belajar di lingkungan alam sekitar (X) sebagai variabel bebas dan keterampilan proses sains (Y) yang bertindak sebagai variabel terikat.

Penentuan sampel menggunakan teknik cluster random sampling, metode pengumpulan data yang digunakan pada penelitian ini yaitu metode observasi, jenis metode observasi yang di gunakan yaitu metode observasi sistematis (Systematic Observation). Metode observasi dilakukan menggunakan instrumen lembar observasi. Rancangan instrumen lembar observasi yang digunakan dalam penelitian ini dapat dilihat pada tabel 1 .

Sebelum penelitian dilaksanakan maka untuk memperoleh hasil pengukuran data yang valid dan reliabel, dilakukan validitas instrumen melalui penilaian ahli terdiri dari 3 validator dan untuk reabilitas pengamatan (observasi) peneliti melakukan brifing dengan memberikan penjelasan kepada semua observer untuk menyamakan persepsi observer. Hal tersebut senada dengan teori menurut Arikunto (2006) menyatakan bahwa "sebelum melakukan pengamatan yang sesungguhnya, para pengamat, pengumpul data perlu dilatih terlebih dahulu untuk menyingkirkan atau menekan sampai sedikit mungkin unsur subjektivitas pengamat".

Teknik analisis data yang digunakan dalam penelitian ini menggunakan uji Paired T-Test. Sebelum uji PairedT-Test digunakan harus dipenuhi persyaratan ujinya yaitu setelah didapat hasil uji normalitas dan uji homogenitas. 
Tabel 1. Rancangan instrumen

\begin{tabular}{|c|c|c|}
\hline No & 1. & 2. \\
\hline Variabel. & $\begin{array}{l}\text { Fasilitas belajar di lingkungan } \\
\text { alam sekitar }\end{array}$ & $\begin{array}{l}\text { Keterampilan } \\
\text { sains }\end{array}$ \\
\hline Indikator & $\begin{array}{l}\text { 1. Menggunakan lingkungan } \\
\text { untuk } \\
\text { pembelajaran. } \\
\text { 2. Mengunjang } \\
\text { untuk mempermudah belajar } \\
\text { siswa. } \\
\text { 3. Menggunakan lingkungan } \\
\text { dalam apersepsi. } \\
\text { 4. Menggunakan lingkungan } \\
\text { sebagai sumber/ media } \\
\text { pembelajaran dalam kegiatan } \\
\text { inti. } \\
\text { 5. Menggunakan lingkungan } \\
\text { sebagai evaluasi. }\end{array}$ & $\begin{array}{l}\text { 1. Mengamati } \\
\text { 2. Mengkomunikasikan } \\
\text { 3. Mengajukan } \\
\text { pertanyaan } \\
\text { 4. Menyimpulkan }\end{array}$ \\
\hline $\begin{array}{l}\text { Metode } \\
\text { Pengumpulan } \\
\text { data. }\end{array}$ & Observasi & Observasi \\
\hline $\begin{array}{l}\text { Instrumen } \\
\text { Metode } \\
\text { Pengolah data. }\end{array}$ & $\begin{array}{l}\text { Lembar Observasi } \\
\text { Kualitatif dengan menggunakan } \\
\text { deskriptif kualitatif yaitu } \\
\text { pemaparan temuan yang ada di } \\
\text { lapangan. }\end{array}$ & $\begin{array}{l}\text { Lembar observasi } \\
\text { Kuantitatif } \\
\text { Dengan menggunakan } \\
\text { uji Pairedt-test yaitu uji } \\
\text { perbedaan dua rata-rata }\end{array}$ \\
\hline
\end{tabular}

\section{HASIL DAN PEMBAHASAN}

Deskripsi Data Hasil Penelitian

Data kuantitatif hasil penelitian yang telah dilakukan di peroleh data keterampilan proses sains (KPS). Adapun deskripsi datadapat dilihat pada tabel 2.

Tabel 2. Distribusi Frekuensi data KPS kelas eksperimen dan kelas kontrol.

\begin{tabular}{cccc}
\hline $\begin{array}{c}\text { Pembelajaran pada kelas } \\
\text { eksperimen }\end{array}$ & \multicolumn{2}{c}{$\begin{array}{c}\text { Pembelajaran pada kelas } \\
\text { kontrol }\end{array}$} \\
\hline Skor & Frekuensi & Skor & Frekuensi \\
$56-60$ & 3 & $54-57$ & 6 \\
$61-65$ & 1 & $58-61$ & 4 \\
$66-70$ & 5 & $62-65$ & 10 \\
$71-75$ & 8 & $66-69$ & 9 \\
$76-80$ & 9 & $70-73$ & 3 \\
$81-85$ & 7 & $74-77$ & 3 \\
$86-90$ & 3 & $78-81$ & 1 \\
Jumlah & 36 & Jumlah & 36 \\
\hline
\end{tabular}

Tabel 2 merupakan deskripsi dari distribusi frekuensi dataketerampilan proses sains kelas eksperimen dan kelas kontrol, yaitu terdapat 3 siswa yangmendapat skor 
terendah berkisar 56-60 pada kelas eksperimen dan 6 siswa di kelas kontrol, dan yang mendapat skor tertinggi berkisar 86-90 terdapat 3 siswa di kelas eksperimen dan 1 siswa di kelas kontrol. Daridistribusi data tersebut dapat disimpulkan bahwa data terdistribusi normal. Deskripsi dari distribusi frekuensi dataketerampilan proses sains kelas eksperimen dan kelas kontrol juga dapat lihat pada gambar 1.

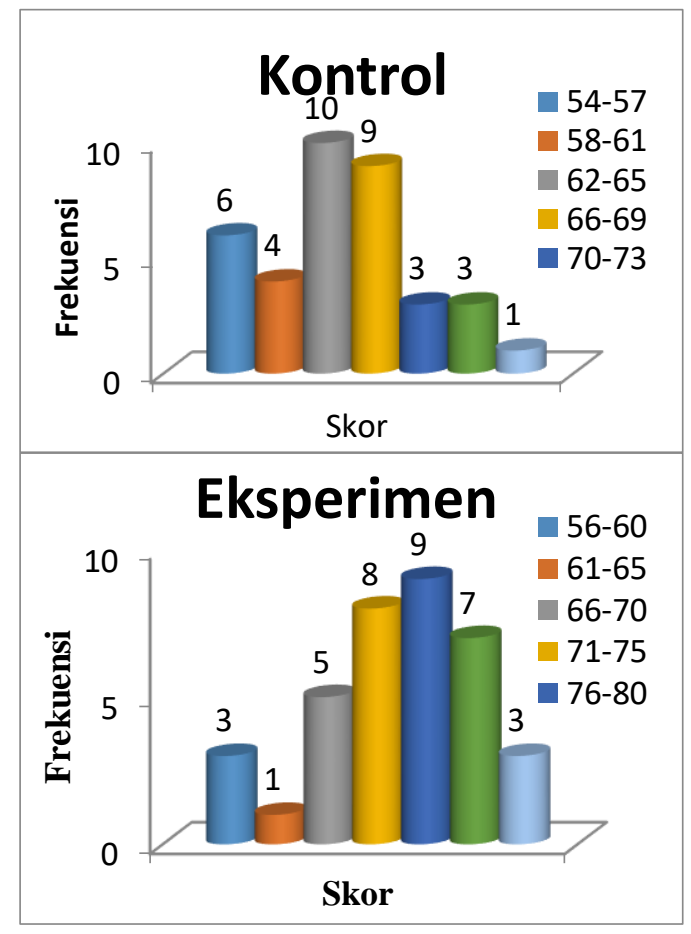

Gambar 1. Diagram data KPS siswa kelas eksperimen dan kelas kontrol.

\section{Statistik Inferensial}

Analisis data meliputi uji normalitas (uji kecocokan chi kuadrat) dan uji homogenitas (uji F). Setelah di dapathasil uji normalitas dan homogenitas baru selanjutnya dilakukan uji perbedaa dua rata-rata menggunakan uji-t untuk menguji hipotesis. Uji normalitas bertujuan untuk mengetahui apakah sampel yang dijadikan penelitian berasal dari populasi berdistribusi normal atau tidak.Dan uji homogenitas bertujuan untuk melihat apakah antara kedua sampel homogen atau tidak.

\section{Uji Normalitas Data}

Data hasil uji normalitas sampel disajikan dalam tabel 3.

\begin{tabular}{lcccc}
\multicolumn{2}{c}{ Tabel 3. Rekapitulasi Interpretasi Uji Normalitas } \\
\hline \multicolumn{1}{c}{ Kelas } & $\mathbf{x}_{\text {hitung }}$ & \multicolumn{2}{c}{$\mathbf{x}^{{ }^{2}{ }_{\text {daf }}}$} & Kesimpula \\
& & $5 \%$ & $1 \%$ & $\mathbf{n}$ \\
\hline Eksperimen & 7,1333 & 9,49 & 13,3 & Terima $\mathrm{H}_{0}$ \\
Kontrol & 5,1187 & 9,49 & 13,3 & Terima $\mathrm{H}_{0}$ \\
\hline
\end{tabular}

Tabel 3. Dapat dijelaskan beberapa hal yaitu diketahui bahwa $X_{h i t}^{2}<X_{\text {daftar }}^{2}$ baik pada kelas eksperimen maupun kelas kontrol. Hal ini menyatakan bahwa keterampilan proses sains siswa sebagai hipotesis berdistribusi normal atau $\mathrm{H}_{0}$ diterima. 


\section{Uji Kesamaan Dua Varians (Uji Homogenitas)}

Data hasil uji homogenitas disajikan dalam tabel 4.

Tabel 4. Nilai F antara Varians Distribusi nilai KPS

\begin{tabular}{lcccc}
\hline \multicolumn{1}{c}{ Kelas } & Varia & \multicolumn{2}{c}{$\mathbf{F}=$} & \multicolumn{2}{c}{$\mathbf{F}_{\text {daf }}$} \\
& $\mathbf{n}\left(\mathbf{S}^{\mathbf{2}}\right)$ & $\mathbf{s}^{\mathbf{2}}$ besar & 10 & $2 \%$ \\
\cline { 2 - 5 } & & $\mathbf{s}^{\mathbf{2}}$ kecil & $\%$ & \\
\hline Eksperim & 66,349 & 1,65 & 1,8 & 2,3 \\
en & 2 & & 0 & 0 \\
Kontrol & 40,228 & & & \\
& 6 & & & \\
\hline
\end{tabular}

Tabel 4. Dapat dijelaskan bahwa $F_{h i t}<F_{d a s}$ sehingga $\mathrm{H}_{0}$ diterima, dengan kata lain kedua populasi mempunyai varian yang homogen.

\section{Uji Hipotesis}

Data keterampilan proses sains berdasarkan hasil uji di atas berasal dari sampel yang berdistribusi normal dan memiliki varians yang homogen maka dapat dilakukan tahap selanjutnya yaitu uji kesamaan dua rata-rata menggunakan uji-t. Hasil perhitungan uji kesamaan dua rata-rata dengan menggunakan uji-t disajikan pada tabel 5.

Tabel 5. Uji Kesamaan dua rata-rata nilai KPS

\begin{tabular}{cccc}
\hline $\boldsymbol{t}_{\text {hit }}$ & $\begin{array}{c}\boldsymbol{t}_{\text {daf }} \\
(\boldsymbol{\alpha}=\mathbf{0 , 0 5})\end{array}$ & $\begin{array}{c}\boldsymbol{t}_{\text {daf }}(\boldsymbol{\alpha}=\mathbf{0 , 0} \\
\mathbf{1})\end{array}$ & $\begin{array}{c}\text { kesimpula } \\
\mathbf{n}\end{array}$ \\
\hline 6,04 & 2,00 & 2.66 & $\mathrm{H}_{1}$ diterima \\
\hline
\end{tabular}

Tabel 4. Dapat dijelaskan beberapa hal yaitu diketahui bahwa $F_{h i t}>F_{d a j}$ sehingga $\mathrm{H}_{1}$ diterima. Hal ini berarti hipotesis yang menyatakan kesamaan dua rata-rata keterampilan proses sainspada kelas eksperimen dan kelas kontrol adalah ada perbedaan rata-rata Keterampilan Proses Sains. Karena dalam uji hipotesis terdapat perbedaan maka dilanjutkan ke uji hipotesis selanjutnya yaitu uji perbedaan dua rata-rata menggunakan uji-t. Hasil perhitungan uji perbedaan dua rata-rata dengan menggunakan uji-t disajikan pada tabel 6.

Tabel 6. Uji Perbedaan dua rata-rata nilai KPS

\begin{tabular}{cccc}
\hline $\boldsymbol{t}_{\text {hit }}$ & $\begin{array}{c}\boldsymbol{t}_{\text {daf }} \\
(\boldsymbol{\alpha}=\mathbf{0 , 0 5})\end{array}$ & $\begin{array}{c}\boldsymbol{t}_{\text {daf }}(\boldsymbol{\alpha}=\mathbf{0 , 0} \\
\mathbf{1})\end{array}$ & $\begin{array}{c}\text { kesimpula } \\
\mathbf{n}\end{array}$ \\
\hline 6,04 & 1,67 & 2.39 & $\mathrm{H}_{1}$ diterima
\end{tabular}

Berdasarkan tabel 6 , dapat dijelaskan beberapa hal yaitu diketahui $t_{\text {hit }}>t_{\text {daf }}$ sehingga $\mathrm{H}_{1}$ diterima. Hal ini mengindikasikan penolakan pada $\mathrm{H}_{0}$, sehingga dapat disimpulkan bahwa rata-rata keterampilan proses sainskelas eksperimenlebih tinggi daripada rata-rata keterampilan proses sainskelas kontrol.

\section{Pembahasan}

Peneliti memberikan tes kepada siswa kelas kontrol dan siswa kelas eksperimen terlebih dahulu sebelum dilakukan penelitian, dengan tujuan untuk dapat mengetahui kemampuan awal siswa. Kemampuan awal siswa bertujuan untuk mengetahui kesiapan 
siswa dalam pembelajaran. Data kemampuan awal siswa yang di peroleh di kelas eksperimen dan kelas kontrol memiliki kemampuan awal yang sama, sehingga dilanjutkan untuk tahap penelitian selanjutnya.

Hasil uji hipotesis terhadap data keterampilan proses sains diperoleh Setelah dilakukan penelitian, pada uji perbedaan dua rata-rata terdapat perbedaan keterampilan proses sains pada kelas eksperimen dan kelas kontrol yang ditunjukkan bahwa $t_{\text {hit }}>t_{\text {daf }}$ dimana $\mathrm{t}_{\text {hit }}$ rata-rata pada materi tekanan adalah 6,04, untuk $\mathrm{t}_{\text {daf }}$ pada taraf signifikansi $\alpha=$ 5\% adalah1,67 dan $\alpha=1 \%$ adalah 2,39, dapat disimpulkan bahwa $\mathrm{H}_{0}$ ditolak atau $\mathrm{H}_{1}$ diterima. Sehingga dapat diketahui bahwa terdapat perbedaan yang signifikan antara keterampilan proses sains siswadi kelas eksperimen dan kelas kontrol. Dengan kata lain keterampilan proses sains siswa kelas eksperimen dan kontrol berbeda secara signifikan. Berdasarkan perbedaan keterampilan proses sains anatara kelas eksperimen dan kelas kontrol, dapat dikatakan bahwa pembelajaran menggunakan fasilitas belajar di lingkungan alam sekitar berpengaruh terhadap keterampilan proses sains.

Penelitian pada kelas kontrol dan kelas eksperimen menggunakan fasilitas belajar di lingkungan alam sekitar yaitu benda-benda yang ada di lingkungan alam sekitar sekolah seperti kayu, bata, batu, botol aqua gelas bekas dapat meningkatkan keterampilan proses sainssiswa terhadap materi tekanan, hukum pascal dan hukum archimedes dimana siswa lebih mudah memahami materi karena pembelajaran lebih kontekstual. Hal tersebut senada dengan pendapat Hamalik (2004) "Belajar pada hakekatnya adalahinteraksi antara individu dan lingkungan. Lingkungan menyediakanransangan (stimulus) terhadap individu dan sebaliknya individu memberikan respons terhadap lingkungan".

Penelitian ini menggunakan lembar observasi penggunaan fasilitas belajar di lingkungan alam sekitar dengan tujuan untuk mengontrol jalannya proses pembelajaran agar penggunaan fasilitas belajar di lingkungan alam sekitar terpenuhi. Penggunaan fasilitas belajar di lingkungan alam sekitar dalam proses pembelajaran dengan indikator yaitu menggunakan lingkungan untuk menunjang pembelajaran, mempermudah belajar siswa, untuk apersepsi, untuk sumber/media pembelajaran dalam kegiatan, dan sebagai evaluasi.

Penelitian ini menggunakan lingkungan untuk menunjang pembelajaran yaitu menggunakan fasilitas belajar dilingkungan alam sekitar seperti batu, dalam percobaan pada materi tekanan sehingga pembelajaran akan lebih mudah, dan lancar. Hal tersebut senada dengan Irhash (2008) menyatakanbahwa "fasilitas belajar adalah semua kebutuhan yang diperlukan oleh peserta didik dalam rangka memudahkan, melancarkan dan menunjang dalam kegiatan belajar disekolah". Menggunakan lingkungan untuk mempermudah belajar siswa yaitu dengan menggunakan fasilitas belajar di lingkunagan alam sekitar misalnya pada percobaan tekanan peserta didik menggunakan batu dan kayu untuk mengetahui besarnya tekanan dan faktor-faktor yang mempengaruhi tekanan, dengan menggunakan batu maka siswa dapat memperoleh informasi berdasarkan pengalaman langsung karena itu siswa akan lebih mudah dalam mengikuti pembelajaran, menggunakan lingkungan untuk apersepsi dalam penelitian ini adalah dengan menggunakan fasilitas belajar dilingkungan alam sekitar dalam apersepsi seperti pada materi tekanan, guru memperlihatkan dua pisau kepada siswa dan memberi demonstrasi dan bertanya kepada siswa mengapa pisau yang runcing lebih mudah digunakan daripada pisau yang tumpul, sehingga siswa akan lebih mudah untuk menjawab dengan benar dan tepat,menggunakan lingkungan sebagai sumber/media pembelajaran dalam kegiatan inti yaitu menggunakan fasilitas belajar di lingkungan alam sekitar sebagai sumber/media dalam pembelajaran seperti siswa dapat mengetahui faktor-faktor yang mempengaruhi tekanan dari percobaan yang telah dilakukan dengan menggunakan batu dan kayu sebagai sumber/media dalam pembelajaran sehingga pembelajan akan lebih konkrit, dan 
menggunakan lingkungan sebagai evaluasi dalam penelitian ini yaitu siswa mampu menjawab pertanyaan-pertanyaan pada lembar kerja siswa dengan benar dan tepat sesuai informasi yang di dapat dari hasil pengamatan lingkungan.

Keterampilan proses sains pada penelitian ini dapat terlihat pada jawaban siswa di lembar kerja siswa. Dengan menggunakan fasilitas belajar di lingkungan alam sekitar maka siswa akan lebih tepat dalam menjawab pertanyaan. Adapun keunggulan dan keuntungan lingkungan sebagai fasilitas/sumber belajar antara lain:

1. Siswa dapat memperoleh informasi berdasarkan pengalaman langsung karena itu proses belajar dan mengajar akan lebih baik.

2. Pelajaran akan lebih konkrit.

3. Penerapan ilmu dalam kehidupan sehari-hari siswa menjadi lebih mudah dan disesuaikan dengan permasalahan yang akan dihadapi.

Penelitian ini juga diketahui bahwa terdapat keterampilan proses sains pada kelas kontrol yang di ambil pada saat proses pembelajaran, walaupun keterampilan proses sains pada kelas eksperimen lebih tinggi. Hal tersebut dikarenakan metode yang digunakan belum efektif, dimana saat guru menjelaskan materi menggunakan metode ceramah membuat siswa bosan dan mengantuk sehingga siswa kurang aktif dan kurang kreatif dalam proses pembelajaran.

Hasil penelitian di atas menunjukkan bahwa meningkatkan keterampilan proses sains siswa dapat dilakukan dengan cara melakukan pembelajaran di luar kelas atau menerapkan pembelajaran berbasis lingkungan yaitu dengan menggunakan fasilitas belajar di lingkungan alam sekitar sebagai sumber belajar terutama untuk materi atau konsep-konsep yang berkaitan dengan lingkungan alam sekitar. Dengan menggunakan fasilitas belajar di lingkungan alam sekitar dalam proses pembelajaran maka siswa mampu mengembangkan serta melestarikan sumber daya alam dan meningkatkan kualitas sumber daya manusia. Belajar melalui pendekatan lingkungan bukan berarti mengeskploitasi terhadap alam, akan tetapi hanya menggunakan jasa alam untuk memenuhi kebutuhan pengetahuan.

\section{PENUTUP}

\section{Simpulan}

Berdasarkan analisis data dan pengujian hipotesis dalam penelitian ini, dapat disimpulkan bahwa "Penggunaan Fasilitas Belajar di Lingkungan Alam Sekitar Berpengaruh Secara Signifikanterhadap Keterampilan Proses Sains".

\section{Saran}

Penggunaan fasilitas belajar di lingkungan alam sekitar mampu membantu menyampaikan materiserta dapat memanfaatkan apa yang disediakan oleh alam yaitu dengan menggunakan model pembelajaran berbasis lingkungan. Pembelajaran menggunakan fasilitas belajar di lingkungan alam sekitar dapat memberikan pengaruh yang signifikan terhadap keterampilan proses sains, hendaknya guru dapat menggunakan fasilitas belajar di lingkungan alam sekitar sebagai sumber belajar dalam pembelajaran fisika dan dalam pembelajaran, siswa hendaknya menggunakan fasilitas belajar di lingkungan alam sekitar saat proses pembelajaran berlangsung untuk dapat meningkatkan keterampilan proses sains.

\section{DAFTAR PUSTAKA}

Arikunto, Suharsimi. 2006. Prosedur Penelitian. Jakara: Rineka Cipta. Hamalik, Oemar. 2004. Prosedur Belajar Mengajar. Jakarta: Bumi Aksara. Hamzah. 2011. Belajar Dengan Pendekatan PAILKEM. Jakarta: Bumi Aksara. 
Irhash, Arianto. 2008. Pengertian Fasilitas Belajar. (online).

http://Sobatbaru.com/2008/10/Pengertian-Fasilitas-Belajar.html. Diunduh pada tanggal 22 mei 2013.

Mahmudin. 2011. Komponen Penilaian Keterampilan Proses Sains. (online). http:/Users/pavilion/Downloads/Komponen\%20Penelitian\%Keterampilan\%20Pros es\%20Sains\%20\%C2\%AB\%20Mahmudin.htm. diunduh pada tanggal 9 juni 2012.

Misbach, Muzamil. 2011. Pengertian Fasilitas Belajar. (online). http://economicsjurnal.blogspot.com/2011/12/pengertian-fasilitas-belajar.html). Diunduh pada tanggal 22 mei 2013.

Mudjiono dan Dimyati. 2006. Belajar dan Pembelajaran. Jakarta: Rineka Cipta.

Permendiknas No.23. 2006. Standar Kompetensi Lulusan. Jakarta: Departemen Pendidikan Nasional.

Sam, Arianto. 2008. Macam-Macam Fasilitas Belajar. (Online) (http://AriantoSam/2008/10/macam-macam-fasilitas-belajar.htm. Diunduh pada tanggal 9 juni 2012).

Trianto. 2010. Model Pembelajaran Terpadu. Jakarta: Bumi Aksara. 